\title{
Balıkesir Örnekleminde Bir Ölçek Geliştirme Çalışması: Afet Hazırbulunuşluk Ölçeği
}

\author{
Barıș Şentuna ${ }^{1}$ \\ ORCID: 0000-0001-9982-8382
}

\author{
Fahri Çak ${ }^{2}$ \\ ORCID: 0000-0002-8895-2297
}

\section{Öz}

Afet hazırbulunuşluğu, hanelerden başlayarak, ulusal düzeye kadar afetler karşısında risk ve tehlikelerin yaratabileceği yıkımları azaltmayı amaçlayan planlama, uygulama ve değerlendirmeleri ifade eder. Bu makale Balıkesir örneklemi kullanilarak hane halklarmın afet hazırbulunuşluğunu ölçmek için kullanılabilecek evrensel bir ölçeği geliştirmeyi amaçlamaktadır. Bu makale dört ana bölümden oluşmaktadır. İlk bölümde hazırbulunuşluk kavramı incelenmiş ve bununla ilgili tanım verilmeye çalışılmıştır. Bunun yanı sıra afet hazırbulunuşluğunu ölçmeye çalışan ölçekler incelenmiş, karşılaştırılmış ve aktarılmıştır. İkinci bölümde örneklemin evrenden çıkartılma süreci Balıkesir ili rakamları ile açıklanmış ( $N=1134)$, araştırmanın kapsayıcılığı bakımından hangi bölgelerde kaçar anket yapıldığı tablo ile açıklanmıştır. Üçüncü bölümde ise bulgulara yer verilmiştir. Açıklayıcı faktör analizi sonrası kullanılan doğrulayıcı faktör analizi ile elde edilen iyilik uyum ölçütleri ile yeni bir model geliştirilmesi ve ilgili soruların analizden çıkartılması ile ilgili süreçler anlatılmıştır. Bulguların devamında ortaya çıkan iyilik uyum ölçütleri ve faktör tablosu tekrar verilmiştir. Ölçek geliştirmenin en önemli parçası olan LISREL programı ile oluşturulan veri yolu analizi diyagramı verilmiştir.

Anahtar Kelimeler: Afet, Hazırbulunuşluk, Ölçek, Balıkesir.

\footnotetext{
${ }^{1}$ Dr. Öğr., Üyesi, Balıkesir Üniversitesi, E-mail: ejderkelebek@gmail.com

${ }^{2}$ Prof. Dr., Balıkesir Üniversitesi, E-mail: cakifahri@yahoo.com

idealkent (c) Kent Araştırmaları Dergisi (Journal of Urban Studies) 


\title{
A Scale Development Study in Balıkesir Sampling: Disaster Preparedness Scale
}

\author{
Barış Şentuna ${ }^{3}$ \\ ORCID: 0000-0001-9982-8382
}

\author{
Fahri Çak ${ }^{4}$ \\ ORCID: 0000-0002-8895-2297
}

\begin{abstract}
Disaster preparedness refers to reduction of risks and dangers caused by disasters by planning, applications, and assessments, starting from households up to national level. This article aims to develop a universal scale for measuring disaster preparedness of households using Balikesir sample. This article is consists of four main parts. In first part of this article, concept of preparedness is examined and definition of preparedness is given. In addition to this, the scales developed for measuring preparedness are analyzed, compared and presented. In second part the preparing of sampling from universe Ballkesir is explained in numbers $(N=1134)$. Inclusiveness of the research was made by deciding on number of questionnaire and places where they will be applied which are presented through tables. In third part the findings are presented. Confirmatory factor analysis which is made after explanatory factor analysis revealed the goodness of fit indexes. Based on that the processes and decision of making another model for the scale and for removing items are explained in detail. In continuing parts of findings, the new goodness of fit findings and factor table are given again. One of the most important part of developing scale namely path diagram made by LISREL is presented.
\end{abstract}

Keywords: Disaster, Readiness, Scale, Balikesir.

\footnotetext{
${ }^{3}$ Asts. Prof. Dr., Balıkesir University, E-mail: ejderkelebek@gmail.com

${ }^{4}$ Prof. Dr., Balıkesir University, E-mail: cakifahri@yahoo.com

idealkent (c) Kent Araştırmaları Dergisi (Journal of Urban Studies) 


\section{Afet Hazırbulunuşluk Ölçekleri}

Afet hazırbulunuşluğu, herhangi bir felaket durumunda kayıp ve yıkımın azaltılmasında temel rol oynayan çok önemli bir faktördür. Hazırbulunuşluk, risk, tehlike ve kırılganlık kavramlarıyla yakından ilgilidir. Bir anlamda hazırbulunuşluk, risk ve tehlikelerin yaratabileceği yıkımları azalmayı amaçlayan planlama, uygulama ve değerlendirmeleri ifade eder. Kırılganlıkların azaltılması da afetlere karşı dirençliğin geliştirilmesi anlamına gelir.

Önlem ve hazırbulunuşluk girişimleri uyarısız meydana gelen tehlikeler için çok daha önemlidir. Ayrıca, hazırbulunuşluk veya hazır olma planlarını hızlı ve etkili bir şekilde harekete geçirme yeteneğini geliştirmek, çok fazla çalışma ve çaba gerektirir çünkü bu, "insanların tehlikeleri nasıl anladıkları, riskleri nasıl yorumladıkları ve insanların afetlere ne ölçüde hazırlanmak istedikleri gibi zorluklarla doğrudan ilişkilidir" (Rañesesa vd., 2018, s.420).

Ancak bu önemine rağmen hazırbulunuşluğu tanımlamak ve onu ölçmek göründügü kadar kolay olmayabilir. Yine de acil durum ve afet müdahalesi ve yönetimi için planlar yaparken ve yöntemler oluştururken bu kavrama bir tanım ve ölçüm geliştirmek gereklidir. Nitekim hazırbulunuşluğu ölçebildiğimiz takdirde, bu bize belirli bir olayla başa çıkmak için ne kadar hazır olduğumuza dair bir gösterge verecektir. Hazırbulunuşluğu ölçemediğimiz takdirde ise, bir olayın potansiyel etkisini değerlendirmek veya farklı planları, sistemleri veya çözümleri birbirleriyle karşılaştırmak daha zor olacaktır.

Hazırbulunuşluğu gerçekten değerlendirmek için yararlı olan genel bir hazırbulunuşluk tanımı yoktur. Sözlükler şöyle bir genel tanım verir: "belirli bir durum için hazırlıklı ya da hazır olma durumu, örneğin, askeri olarak savaşa hazır olma durumu" (Cambridge English Dictionary, 2020). Bu tanımdaki "hazırlıklı ya da hazır olma durumu" aslında çok muğlak kalmaktadır çünkü "neye", "ne kadar" hazırlıklı olmadan söz edildiği belli değildir. Dolayısıyla bir bağlama oturtulmadığı ve ölçümlenir bir hale gelmediği sürece bu kavram kullanışlı olmaktan çıkar. Bununla birlikte literatür görülen bazı akademik tanımlar da bahsedilen sorundan ari değildir. Birkaç tanım aşağıda sunulmuştur:

Afete hazırbulunuşluk, genellikle bir olaydan önce, müdahale ve kurtarma için acil durum planları geliştirerek, bu planların hızlı ve etkili bir şekilde uygulanması ve tehlikeler ve riskler konusunda halkın sürekli farkındalığı yoluyla toplumu veya insanları hazırlayarak doğal afetlerin şiddetini azaltmaya veya ortadan kaldırmaya yardımcı olabilecek önlemler olarak ifade edilir (Rañesesa vd., 2018, s.420). 
Dünya Sağlık Örgütü (WHO)'ne göre afete hazırbulunuşluk; etkili bir müdahale için personel, fon, ekipman ve malzemelerin güvenli bir ortamda organizeli hareketliliğini sağlayan önlemlerdir (WHO/EHA, 2002, s.21).

FEMA'nın hazırbulunuşluk tanımı ise şöyledir:

Afetlere hazırlanma, afetlerin etkilerini hafifletme, bir afetten sonra toplumun ihtiyaçlarına cevap verme ve etkili iyileşme çabaları başlatma süreçlerinde vatandaşları, toplumları, devleti, yerel yönetimleri ve profesyonel acil durum çalışanlarını güçlendirmek için liderlik, eğitim, hazırlık ve egzersiz desteği, teknik ve mali yardım (Vahle ve Beatty, 1993)

Farklı vurgulara sahip olsalar da yukarıdaki tanımlamaların ortak yanı afet öncesi bir sürece işaret etmeleridir. Bu süreçte yapılacak işler ve alınacak önlemler gerçekte nispidir çünkü hiçbir birey/toplum/topluluk/örgüt afetlere mutlak anlamda hazır olamaz; ancak diğerlerine ve/veya kendi geçmişine k1yasla bir hazırbulunuşluk seviyesine sahip olur. İşte bu seviyeyi belirlemenin yolu afet hazırbulunuşluk ölçekleridir.

Bir acil durum veya afet meydana gelmeden önce aktörlerin hazırbulunuşluk seviyelerini ölçmeyi amaçlayan ölçekler göstergeler kullanılırlar. Hazırbulunuşluğa konu olan olaya bağlı olarak, farklı faktörler hazırlık durumunu etkileyebilir. Hazırbulunuşluk öncelikle boyutları itibariyle farklılaşabilir. Bu bağlamda mevcut hazırbulunuşluk ölçekleri incelendiğinde 5 temel boyuta göre ölçekler geliştirildiği gözlenmektedir:

- Kişisel/Hane Halkı Hazırbulunuşluğu: Bir kişinin veya hane halkının belirli bir olayla başa çımaya yönelik hazırbulunuşluk düzeyini ifade eder.

- Örgütsel Hazırbulunuşluk: Bir müdahale kuruluşu, ör. itfaiye, insanlara yardım etmeye hazırlıklı olma ile ilgilenebilirken, özel sektörde faaliyet gösteren bir şirket afetler, acil durumlar veya ekonomik krizlerle başa çıkmak için kendini hazırlamaya odaklanabilir.

- Bölgesel Hazırbulunuşluk: Bölgesel ölçekte hazırbulunuşluk, bir bölgenin, ör. bir il, ilçe veya belediye, kaza durumunda sakinlerinin güvenliğini sağlamak üzere yürüttü̆̆ü eylemleri ifade eder.

- Ulusal Hazırbulunuşluk: Daha büyük ölçekte, toplum hazırbulunuşluğu bir ülkenin büyük bir felaketle başa çıkma yeteneği, yani ulusal afet hazurbulunuşluğu olabilir.

- Küresel Hazırbulunuşluk: En geniş boyutuyla küresel hazırbulunuşluk küresel bir felaketle, özellikle pandemik hastalıklarla başa çıkmak için yapılan, yürütülen faaliyetleri içerir. 
Aşağıdaki tabloda (Tablo 1) mevcut literatürde tespit edilen bazı afet hazırbulunuşluk ölçeklerinin hangi afet olayları için hangi boyutta ve hangi amaçlar için geliştirildiklerinin bir özeti sunulmaktadır.

Tablo 1: Bazı Hazırbulunuşluk Ölçeklerinin Sınıflandırılması

\begin{tabular}{|c|c|c|c|}
\hline Kaynak & Olay & Boyut & Ölçümün amacı \\
\hline $\begin{array}{l}\text { Davidson ve } \\
\text { Lambert (2001) }\end{array}$ & Kasırgalar & Bölgesel & $\begin{array}{l}\text { ABD eyaletlerinin kasırgalarla başa } \\
\text { çıkma için hazırbulunuşluklarını kar- } \\
\text { şılaştırmak }\end{array}$ \\
\hline Cardona (2005) & Genel afet & Ulusal & $\begin{array}{l}\text { Ülkeler arasındaki afete hazırbulu- } \\
\text { nuşluk durumunu karşılaştırmak }\end{array}$ \\
\hline Simpson (2008) & Genel afet & Bölgesel & $\begin{array}{l}\text { Şehirler arasındaki afete hazırbulu- } \\
\text { nuşluk durumunu karşılaştırmak }\end{array}$ \\
\hline Rachmalia vd.(2011) & Tsunami & Kişisel & $\begin{array}{l}\text { Kişisel tsunami deneyimi ile tsunami } \\
\text { hazırbulunuşluğu arasındaki ilişkiyi } \\
\text { analiz etmek }\end{array}$ \\
\hline WHO (2011) & Pandemik grip & Küresel & $\begin{array}{l}\text { Farklı ülkelerin bir grip salgını ile baş } \\
\text { etmeye hazırbulunuşluk durumla- } \\
\text { rını değerlendirmek ve karşılaştır- } \\
\text { mak }\end{array}$ \\
\hline Baker (2011) & Kasırgalar & Kişisel & $\begin{array}{l}\text { Hane halkı hazırbulunuşluk duru- } \\
\text { munu analiz etme, hazırbulunuşluk } \\
\text { ile demografik değişkenler arasın- } \\
\text { daki ve hazırbulunuşluk ve yardım } \\
\text { malzemelerine talep arasındaki iliş- } \\
\text { kiyi bulma }\end{array}$ \\
\hline Nishigami (2015) & Doğal afetler & Kurumsal & $\begin{array}{l}\text { Hastane Hemşireliği Bölümü Doğal } \\
\text { Afetlere Hazırlık Ölçeğinin güveni- } \\
\text { lirliğini ve geçerliliğini doğrulamak }\end{array}$ \\
\hline Rañesesa vd. (2017) & Depremler & Bölgesel & $\begin{array}{l}\text { Doğal tehlikeler söz konusu oldu- } \\
\text { ğunda Auckland banliyösündeki } \\
\text { toplulukların ne kadar hazır oldu- } \\
\text { ğunu ölçmek }\end{array}$ \\
\hline Ilo vd. (2018) & $\begin{array}{l}\text { Afet ekipmanları- } \\
\text { nın (yangın } \\
\text { söndürücüler, kum } \\
\text { kovaları, acil çıkış } \\
\text { kapıları vb.) } \\
\text { mevcudiyet oranı }\end{array}$ & Kurumsal & $\begin{array}{l}\text { Afet ekipmanlarının mevcudiyeti ile } \\
\text { afet hazırbulunuşluğu ve üniversite } \\
\text { kütüphanelerinde müdahale uygula- } \\
\text { maları arasındaki ilişkiyi analiz eder }\end{array}$ \\
\hline Patrisina (2018) & Tsunami & Kişisel & $\begin{array}{l}\text { Bir bireyin afete hazırlık durumunun } \\
\text { ölçülmesi }\end{array}$ \\
\hline Dikmenli (2018) & Genel afet & Kişisel & $\begin{array}{l}\text { Öğretmen adaylarının afet bilincini } \\
\text { belirlemek }\end{array}$ \\
\hline
\end{tabular}

Bir hazırbulunuşluk ölçeği tipik olarak bir dizi gösterge ile oluşturulur. Farklı etkinlik türleri için literatürde kullanıldığı gözlenen birkaç gösterge örneği şunlardır: 
- (Kişisel) tsunami hazırbulunuşluğu: Bilgi, bireysel acil durum planlaması ve kaynak mobilizasyon kapasitesi (Rachmalia vd., 2011).

- (Kişisel) kasırga hazırbulunuşluğu: Üç gün yiyecek, üç gün pil içeren el feneri, ilaçlar, içilebilir su, eldeki önemli kağıtlar, açık hava ızgarası, jeneratör (Baker 2011).

- (Küresel) pandemik influenza hazırbulunuşluğu: ulusal komite / görev gücünün ne sıklıkta toplandığı, bir pandemi sırasında gözetim önlemleri, sağlık tesisleri öncelikleri ve müdahale stratejileri, vb. (WHO, 2001).

Afet hazırbulunuşluk ölçeklerinin çoğu farklı alanları (bölgeler, şehirler, ilçeler, ülkeler) birbirleriyle karşılaştırmak için kullanılabileceği gibi belli bir alanın hâlihazırdaki hazırbulunuşluğunu tespit amaçlı olarak da kullanılabilirler. Her iki durumda da hazırbulunuşluk ölçekleri kentler, bölgeler, ülkeler ve örgütlerin sakinleri/çalışanları ve karar alıcılarının eylem ve kararlarında etkili bir faktör olabilir.

Aşağıda ayrıntıları verilecek olan ölçek ise, 2018-2019 yıllarında Balıkesir' in 12 ilçesinde gerçekleştirilen bir saha çalışmasına temel oluşturan, spesifik bir afet türünden ziyade katılımcların yaşam bölgelerindeki genel afetleri esas alan, Türkiye koşullarına ve Türk kültürüne duyarlı, hane halkları için hazırlanmış bir ölçektir.

\section{Yöntem}

\section{Evren ve Örneklem}

Çalışmamızın evrenini Balıkesir ili oluşturmaktadır. Çalışmamızda toplamda 1134 kişiden veri toplanmış olup kayıp veri analizi yapıldıktan sonra ( $N=1134)$ kişi ile analiz yapılmıştır. Bazı temel bileşenler Tablo 3'te rapor edilmiştir. Proje başvurusunu yaptığımız yıl itibariyle TUIKK 2016 verilerine göre Balıkesir toplam nüfusu 1.196.176'dir. Bu nüfus, 596.896 erkek ve 599.280 kadından oluşmaktadır. Bu nüfusun cinsiyete göre dağılımı \%49,90 erkek, $\% 50,10$ kadın olacak şekildedir. Ancak araştırmamızın analiz ünitesi bireyler değil, hane halkıdır. O nedenle örneklem grubu belirlenirken bireyler değil, hane sayıları esas alınmıştır. TUIK 2016 verilerine göre Balıkesir'de hane sayıs1 395 bin 499'dir. Örneklem büyüklügü hesaplanırken basit tesadüfi örnekleme yöntemi kullanılmıştır. Kabul edilebilir hata oranı $+/-3 \%$ ve $95 \%$ güven seviyesi esas alınarak 1065 haneden oluşan örneklem büyüklüğü elde edilmiştir. Bununla ilgili kullanılan formül aşağıdaki gibidir: 


$$
\frac{\frac{z^{2} \times p(1-p)}{e^{2}}}{1+\left(\frac{z^{2} \times p(1-p)}{e^{2} N}\right)}
$$

(N: evren büyüklüğü; e: hata oranı; z: güven seviyesi; p: oran değeri).

Balıkesir' in merkez ilçeleri dâhil olmak üzere toplam 20 ilçesi, 892 köyü ve 53 belediyesi bulunmaktadır. Örneklemde kır-kent ayırımının hanelerin dağılımına göre orantılanması öngörülmüş̧ür. Ancak bu konuda hesaplama yapma güçlüğü bulunmaktadır. Çünkü "2013 yılı yerel seçimleri öncesinde yapılan kanuni düzenleme illerin birçoğunda il ve ilçe merkezleri dışında yer alan yerleşim merkezlerinin statüleri değiştirilmiş ve il ve ilçe sınırları içinde değerlendirilmeye başlanmıştır. Nüfus istatistiklerinde de il ve ilçe merkezi nüfusları 2013 yılından itibaren bu yeni düzenleme çerçevesinde hesaplanmaya başlanmıştır. Bu nedenle Balıkesir ilinde 2013 yılından itibaren nüfusunun tamamı il ve ilçe merkezlerinde yaşıyor olarak görülmektedir. Kentleşme oranı da fiilen olmasa da hukuki düzenleme çerçevesinde $\% 100$ olarak görülmektedir. Bu hukuki düzenlemeden önceki TUIK 2012 verilerine göre Bal1kesir' de kentsel nüfus oranı \%61,3'tür. Dolayısıyla örneklemde kır-kent ay1rıminı hesaplarken bu 2012 verilerini esas almak bir zorunluluktur. Buna göre örneklemin yaklaşık \%62'sinin kentsel alanlardaki hanelerden \%38' inin de kırsal alanlardaki hanelerden oluşturulması öngörülmüştür. Diğer bir deyişle, 1065 haneden oluşan örneklemin 660 tanesi kentsel alanlardaki hanelerden, 405 tanesi de kırsal alanlardaki hanelerden oluşturulması öngörülmüştür.

Örnekleme dâhil edilecek ilçelerin oluşturulmasında evreni temsil kriterine özellikle dikkat edilmiştir. Bir yandan coğrafi yapı çeşitliliğinin, bir yandan demografik yapı çeşitliliğinin diğer yandan da sosyal ve kültürel yapı çeşitliliğinin örneklemde temsil edilebilmesi için a) kıyı bölgeler, b) kent merkezi, c) iç/karasal bölgeler tipolojisi kullanılmıştır. Bu çerçevede kıyı bölgeleri temsil etmek üzere Bandırma, Erdek, Ayvalık ve Edremit ilçeleri; kent merkezini temsil etmek üzere Karesi ve Altieylül ilçeleri; iç/karasal bölgeleri temsil etmek üzere de Manyas, Kepsut, Dursunbey, Savaştepe, Sındırg1 ve İvrindi ilçeleri örnekleme dahil edilmiştir. Araştırmanın planlanması sırasında geçen süredeki nüfus artışı göz önünde bulundurularak ihtiyat payı da örnekleme dahil edilmiştir. 
Tablo 2: İlçelere Göre Balıkesir Nüfusu ve İhtiyat PaylıÖngörülen Örneklem Büyüklükleri

\begin{tabular}{|c|c|c|c|c|c|c|c|c|}
\hline Yll & İlçe & $\begin{array}{l}\text { İlçe } \\
\text { Nü- } \\
\text { fusu }\end{array}$ & $\begin{array}{l}\text { Nüfus } \\
\text { Yüz- } \\
\text { desi }\end{array}$ & $\begin{array}{l}\text { Nüfusa } \\
\text { Oranlı } \\
\text { Örnek- } \\
\text { lem }\end{array}$ & Ek & $\begin{array}{l}\text { Toplam } \\
\text { Örnek- } \\
\text { lem }\end{array}$ & $\begin{array}{l}\text { Kentsel } \\
\text { Örnek- } \\
\text { lem } \\
(\% 62)\end{array}$ & $\begin{array}{l}\text { Kirsal } \\
\text { Örnek- } \\
\text { lem } \\
(\% 38)\end{array}$ \\
\hline 2017 & Karesi & 178.105 & $\% 15$ & 160 & 20 & 180 & 112 & 68 \\
\hline 2017 & Altıeylül & 177.867 & $\% 15$ & 160 & 20 & 180 & 112 & 68 \\
\hline 2017 & Bandırma & 152.480 & $\% 13$ & 139 & 20 & 159 & 99 & 60 \\
\hline 2017 & Edremit & 148.341 & $\% 12,31$ & 130 & 20 & 150 & 93 & 57 \\
\hline 2017 & Ayvalık & 68.831 & $\% 6$ & 64 & 20 & 84 & 52 & 32 \\
\hline 2017 & Dursunbey & 36.324 & $\% 3,01$ & 32 & 20 & 52 & 32 & 20 \\
\hline 2017 & Sindirg1 & 33.753 & $\% 2,80$ & 30 & 20 & 50 & 31 & 19 \\
\hline 2017 & İvrindi & 32.882 & $\% 2,73$ & 30 & 20 & 50 & 31 & 19 \\
\hline 2017 & Erdek & 32.317 & $\% 3$ & 32 & 20 & 52 & 32 & 20 \\
\hline 2017 & Kepsut & 23.342 & $\% 2$ & 21 & 20 & 42 & 26 & 16 \\
\hline 2017 & Manyas & 19.356 & $\% 1,61$ & 17 & 20 & 37 & 23 & 14 \\
\hline \multirow[t]{2}{*}{2017} & Savaştepe & 18.187 & $\% 1,51$ & 16 & 20 & 36 & 22 & 14 \\
\hline & TOPLAM & 921.785 & $\% 78$ & 831 & 240 & 1072 & 665 & 407 \\
\hline 2017 & $\begin{array}{l}\text { Diğer } \\
\text { İlçeler }\end{array}$ & 283.039 & $\% 22$ & 234 & & & & \\
\hline \multicolumn{2}{|c|}{ GENEL TOPLAM } & & $\% 100$ & 1065 & & 1072 & 665 & 407 \\
\hline
\end{tabular}

Buna göre 2017 yılı itibariyle toplam nüfusu 1.204.824 olan Balıkesir'in örnekleme dâhil edilen 12 ilçesinde ilçe nüfusları ve toplam nüfus içindeki oranları dikkate alındığında görülecektir ki söz konusu 12 ilçenin toplam nüfusu 921.785 ve toplama oranı \%78'dir. Geri kalan diğer ilçelerdeki 283.039 kişinin (\%22) payı da 1065 hanelik örnekleme eşit bir şekilde dağıtıldığında her bir ilçeye ortalama 20'şer ek kişi eklenmiştir. Böylece ilçeler bazında elde edilen toplam örneklem büyüklükleri kendi içlerinde kentsel bölgeler için \%62, kırsal bölgeler için \%38 oranında hesaplanarak ayrıca dağılımları yapılmış ve sonuçta Tablo 2'de gösterilen ihtiyat paylı örneklem büyüklükleriyle anketlerin yapılması öngörülmüştür.

Saha çalışmasına başladıktan sonra gerçekleşen fiili örneklem büyüklüklerinin dağılımı ise Tablo 3'te görüldüğü şekilde olmuştur: 
Tablo 3: İlçe, Mahalle ve Köylere Göre ve Kentsel/Kırsal Ayırımına Göre Fiili Örneklem Büyüklüklerinin Dağılımı

\begin{tabular}{|c|c|c|c|c|c|c|}
\hline & İLÇE & $\begin{array}{l}\text { MAHALLE } \\
\text { SAYISI }\end{array}$ & $\begin{array}{l}\text { KÖY } \\
\text { SAYISI }\end{array}$ & $\begin{array}{l}\text { KENTSEL } \\
\text { ANKET } \\
\text { SAYISI }\end{array}$ & $\begin{array}{l}\text { KIRSAL } \\
\text { ANKET } \\
\text { SAYISI }\end{array}$ & $\begin{array}{l}\text { TOPLAM } \\
\text { ANKET } \\
\text { SAYISI }\end{array}$ \\
\hline & ALTIEYLÜL & 10 & 6 & 127 & 67 & 194 \\
\hline & KARESI & 9 & 6 & 81 & 70 & 151 \\
\hline & BANDIRMA & 6 & 8 & 101 & 59 & 160 \\
\hline & ERDEK & 4 & 2 & 35 & 20 & 55 \\
\hline & MANYAS & 5 & 2 & 38 & 23 & 61 \\
\hline & EDREMIT & 11 & 4 & 101 & 60 & 161 \\
\hline & AYVALIK & 5 & 3 & 64 & 32 & 96 \\
\hline & İVRİNDİ & 4 & 4 & 29 & 20 & 49 \\
\hline & KEPSUT & 4 & 2 & 35 & 21 & 56 \\
\hline & DURSUNBEY & 6 & 2 & 36 & 20 & 56 \\
\hline & SINDIRGI & 5 & 2 & 30 & 20 & 50 \\
\hline & SAVAŞTEPE & 6 & 2 & 30 & 20 & 50 \\
\hline TOPLAM & 12 & 75 & 43 & 707 & 432 & 1139 \\
\hline
\end{tabular}

Saha veri toplama analizinde farklı sorularda farklı kayıplar olsa da; 5 anket tamamen boş döndüğünden genel olarak 1134 sayısına başarıyla ulaşılmış ve örneklemimiz 1134 olarak kalmıştır.

Tablo 4: Betimleyici İstatistik

\begin{tabular}{|c|c|c|c|}
\hline K. Bilgiler & Alt Gruplar & $\begin{array}{l}\text { Frekans } \\
\text { (f) }\end{array}$ & $\begin{array}{l}\text { Yüzde } \\
(\%)\end{array}$ \\
\hline \multirow[t]{2}{*}{ Kırsal/Kentsel } & Kursal & 430 & 37,9 \\
\hline & Kentsel & 704 & 62,1 \\
\hline \multirow{9}{*}{ Gelir } & $0-800 \mathrm{TL}$ & 57 & 5,1 \\
\hline & 801-1600 TL & 203 & 17,9 \\
\hline & $1601-2500 \mathrm{TL}$ & 284 & 25 \\
\hline & 2501-3600 TL & 214 & 18,9 \\
\hline & 3601-5000 TL & 206 & 18,2 \\
\hline & $5001-7600 \mathrm{TL}$ & 83 & 7,3 \\
\hline & $7601-10000 \mathrm{TL}$ & 39 & 3,4 \\
\hline & 10001-15000+TL & 28 & 2,5 \\
\hline & 10001-15000+TL & 28 & 2,5 \\
\hline \multirow[t]{2}{*}{ Nereli } & Balıkesirli & 936 & 82,5 \\
\hline & Balıkesirli değil & 189 & 16,7 \\
\hline \multirow{4}{*}{ Ev Mülkiyeti } & Kira & 216 & 19,1 \\
\hline & Kendimizin & 876 & 77,4 \\
\hline & Lojman & 7 & 0,6 \\
\hline & Diğer & 29 & 2,6 \\
\hline \multirow[t]{2}{*}{ Evin Türü } & Apartman & 518 & 45,7 \\
\hline & Müstakil & 602 & 53,1 \\
\hline \multirow{4}{*}{ Evin Ruhsatı } & 2000 yılından önce & 594 & 52,5 \\
\hline & 2000 yilı ve sonrası & 341 & 30,2 \\
\hline & Ruhsatsız & 153 & 13,5 \\
\hline & Cevapsiz & 43 & 3,8 \\
\hline
\end{tabular}


Örneklem grubuna dâhil edilen hanelerin \% 62,1'i ( $\mathrm{N=430)}$ kentsel yerleşim yerlerinden $\% 37,9^{\prime} \mathrm{u}(\mathrm{N}=704)$ da kırsal yerleşim yerlerinden teşekkül etmiştir. Afetlere hazırbulunuşluk kuşkusuz bireylerin ve ailelerin ekonomik gelir seviyeleriyle de ilgilidir. Bu açıdan örneklemdeki hanehalklarına toplam gelir durumları sorulmuştur. Buna göre hanehalklarının yarıdan fazlası $(\% 62,5)$ 1601-5000 TL arasinda gelire sahiptir (Tablo 4). Daha spesifik olarak hanehalklarının \%18'i 801-1600 TL gelir grubunda (N=203), \%25,2'i 1601-2500 TL gelir grubunda $(\mathrm{N}=284), \% 19^{\prime} \mathrm{u}$ 2501-3500 TL gelir grubunda $(\mathrm{N}=284)$, \%18,3'ü 3501-5000 TL gelir grubunda (N=206) , \%7,3'ü 5001-7500 TL gelir grubunda ( $\mathrm{N}=83$ ) yer alırken \%5,06's 800 TL veya daha az gelire sahiptir ( $\mathrm{N}=57)$. Bu veriler Balıkesir' de hanehalklarının afet hazırbulunuşluğu için yeterli ekonomik altyapılarının bulunmadığına da işaret etmektedir. Hanehalklarının aslen yaşadıkları ilden (Balıkesirli) olup olmadıkları onların afet farkındalığına, hazırbulunuşluğuna ve sosyal sermayelerine etki eden bir faktör olabileceği düşüncesiyle nereli oldukları sorusu da yöneltilmiştir. Bulgulara göre hanehalklarının büyük çoğunluğu $(\% 82,5)(\mathrm{N}=936)$ aslen Balıkesirlidir. İkamet edilen evin özellikleri (mülkiyeti, türü, ruhsat durumu, ikamet süresi vb.) de hanehalklarının afete hazırbulunuşluk tutum ve davranışlarını etkileyebilir. Bulgular göstermektedir ki hanehalklarının büyük çoğunluğu kendi evlerinde yaşamaktadırlar $(\% 77,4) \quad(\mathrm{N}=876)$. İkametgâhların yaklaşık yarısı $(\% 45,7)(\mathrm{N}=518)$ apartman dairesi, yarıdan biraz fazlası da (\%53) $(\mathrm{N}=602)$ müstakil evlerdir (Tablo 3). Öte yandan ikametgâhların yarıdan fazlasının $(\% 52,5)(\mathrm{N}=594)$ ruhsat tarihi 2000 yllından öncesine aittir ve \%13,5'inin hiç ruhsatı yoktur ( $\mathrm{N}=153)$ (Tablo 4). 2000 yılı ve sonrasinda ruhsatı alınan evlerin oranı sadece \%30'dur ( $\mathrm{N}=341$ ). Bu durum Balıkesirli hanehalklarının yaklaşık \%70'inin ikametgâhları açısından afetler için çok kırılgan bir noktada olduklarına işaret etmektedir.

\section{Ölçek Geliştirme Süreci}

Ölçek geliştirme sürecinin ilk aşamasında uzman görüşlerine ve ilgili literatüre başvurulmuş, 26 soruluk bir soru havuzu oluşturulmuş ve bu soru havuzundan kırsal kesimde yapılacak anketler göz önünde bulundurularak, uzmanların üzerinde anlaşamadıkları sorular anketten çıkartılmıştır. Sorular 15 soruya indirgenmiştir. Anketörler vasıtasıyla, yüz yüze görüşme metoduyla, seçilen her ilçeden 100 adet olmak üzere; toplamda 1500 katılımcıya ulaşılması hedeflenmiştir. Ancak Erdek, Manyas, İvrindi, Savaştepe, Sındırgı, Kepsut, Dursunbey ilçelerindeki katılımclların anketlere geri dönüşü nispe- 
ten az olduğundan dolayı toplamda 1139 kişiye anketler uygulanmıştır. Datadan kayıp veriler ayıklandıktan sonra, 1134 kişi ile analize devam edilmiştir. Ölçeği yanıtlayan katılımcılar maddelere (1) kesinlikle hayır; (2) hayır, (3) evet, (4) kesinlikle evet arasında değişen 4 kategorili derecelendirme ölçeğine göre soruları yanıtlamışlardır. Dolayısıyla ölçek, 4’lü Likert tipi bir ölçektir. Ölçek kullanımında çeşitli tartışmalar olsa da 4'lü Likert tipi ölçek kullanımının katılımcıların muğlak cevaplar vermesini engelleyerek ve daha çok düşünmeye sevk edeceği yönünde kanı vardır. (Garland, 1991) Ölçekteki maddeler (Kesinlikle evet: 3 21-4.00, Evet: 241-3.20, Hayır: 1.61-2.40, Kesinlikle hayır: 0.81-1.60:) alacak şekilde puanlandırılmıştır. Başta 26 olan soru sayısı, 15 'e indirilmiştir. Ölçeğin tamamından alınabilecek en alt puan 15, en üst puan 60 olmuştur.

\section{Verilerin Analizi}

Araştırma kapsamında faktör analizinin yapılabilmesi için gerekli görülen örneklem büyüklüğü incelenmiş, çalısma grubu yeterli görülmüştür (Tabachnick ve Fidell, 2001). "Afet ve Hazır Bulunuşluk Ölçeği" nin yapı geçerliğini belirlemek için Varimax döndürme ile temel bileşenler analizi kullanılarak Açıklayıcı Faktör Analizi (AFA) yapılmıştır. Analizde faktör yükleri en az ,40 olarak belirlenmiştir (Şencan 2005; Walker ve Maddan, 2013). Ölçeğin alt boyutları ve toplam güvenirlikleri için Cronbach Alpha katsayısı hesaplanmıştır. Analiz sonucunda her faktörde kabul edilir en az 2 madde olmalldır (Çam ve Baysan-Arabacı, 2010). Ayrıca AFA ile ortaya konulan yapının doğruluğunun test edilebilmesi için Doğrulayıcı Faktör Analizi (DFA) yapılmıştır.

\section{Bulgular}

Ölçeğin kendi içindeki tutarlılığı (ölçeği oluşturan maddelerin kendi aralarındaki ilişkilerin anlamlı olması) Pearson Momentler Çarpım Korelasyon Katsayısı ile belirlenmektedir. Deneme ölçeğinde yer alan 12 maddeden hangilerinin birbiriyle uyumlu olduğunu belirlemek amaciyla korelâsyonlara dayalı madde analizi yöntemi ile ölçekteki her madde için madde toplam test korelasyonları hesaplanmıştır. Faktör analizinden önce datanın stabilitesi analiz edilmiştir. Korelasyon Matrisi sonuçları bizlere yükü ,40'ten fazla olan pek çok soru göstermiştir. Kaiser-Meyer-Oklin değeri ,84 çıkmış, sahip olunması beklenen en düşük değeri geçmiştir (Kaiser 1970). Barlett'in küresellik testi (Barlett, 1954) istatistiksel olarak anlamlı çıkmıştır ( $p<0,001)$. Bu ön testler ölçeğin faktör analizine uygun olduğunu göstermektedir. 
Açıklayıcı faktör analizi Eigen değerleri 1'in üzerinde olan 4 faktör ortaya çıkartmıştır. Bu faktörler sırasıyla toplam varyansın yüzde $34,7^{\prime}$ den yüzde 6,89'a kadar çeşitli açıklayıcılık değerleri göstermiş, grafiksel serpilme diyagramı çizimi yapılmış; Cartell' in (1966) çizim testine göre, 3. faktörlerden sonra keskin bir düşüş gözlemlenmiştir (Tablo 5.). Bu sebepten dolayı 4 faktörlü yapı tercih edilmiştir.

Tablo 5: AFA Serpilme Diyagramı Çizim Grafiği

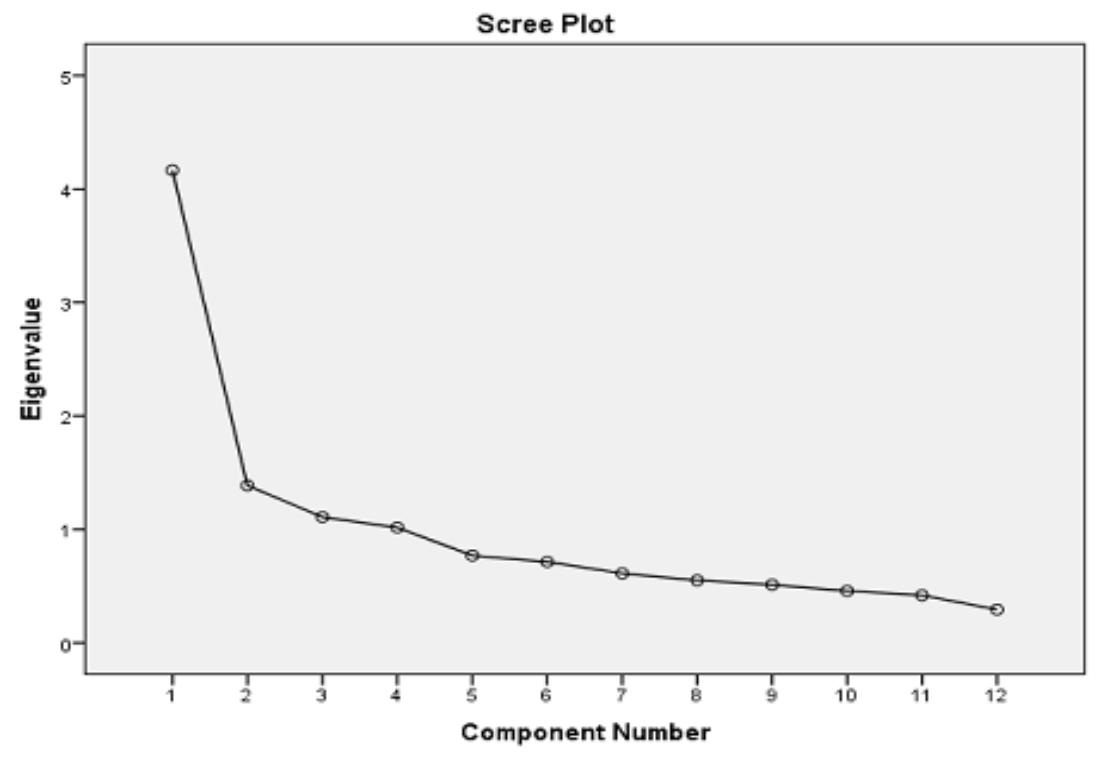

Afet ve Hazır Bulunuşluk Ölçeği, 15 soru ve 4 alt boyuttan oluşmaktadır. Ölçek, toplam varyansın 59,99'unu açiklamaktadır. 4 faktör sırasıyla Afet Fiziksel Koruma (AFK), Planlama (AP), Afet Yardım (AY), Afet Uyarı ve Sinyaller (AUS) şeklinde isimlendirilmiştir. AFK'nin faktör yükleri ,79 ile ,40 arasında değişen 7 maddeden oluşmaktadır; ortalaması 13,76 çıkmıstır $(X=13,76$; $\mathrm{SS}=4,52, \mathrm{~N}=1134$; bkz. Tablo 6.) ve toplam varyansın \%34,47'sini açıklamaktadır. AP'nin faktör yükleri ,84 ve ,75 arasında değişen 3 maddeden oluşmaktadır; ortalaması 5,69 çıkmıştır ( $\mathrm{X}=5,92 ; \mathrm{SS}=2,22, \mathrm{~N}=1134)$ ve toplam varyansin \%10,65'ini açılamaktadır. AY'nin faktör yükleri ise ,78 ve ,60 arasında değişen 3 maddeden oluşmaktadır; ortalaması 8,52 çıkmıştır ( $X=8,52$; SS=1,98, $\mathrm{N}=1134$ ) ve toplam varyansın $\% 7,97$ 'sini açıklamaktadır. AUS'un faktör yükleri ,80 ve ,76 arasında değişen 2 maddeden oluşmaktadır; ortalaması 3,60 ç1kmıştır $(X=3,60$; $S S=1,43, N=1134)$ ve toplam varyansın \%6,89'unu açıklamaktadir (Tablo 5.). 
Tablo 6: Afa Faktör Yükleri

\begin{tabular}{|c|c|c|c|c|}
\hline & \multicolumn{4}{|c|}{ Faktörler } \\
\hline & $\begin{array}{l}\text { Afet } \\
\text { Fiziksel } \\
\text { Koruma } \\
\text { (AFK) }\end{array}$ & $\begin{array}{l}\text { Afet } \\
\text { Planlama } \\
\text { (AP) }\end{array}$ & $\begin{array}{l}\text { Afet } \\
\text { Yardım } \\
\text { (AY) }\end{array}$ & $\begin{array}{l}\text { Afet Uyarı } \\
\text { ve Sinyaller } \\
\text { (AUS) }\end{array}$ \\
\hline $\begin{array}{l}\text { Afet durumunda ihtiyaç duyacağınız mal- } \\
\text { zemeleri içeren afet çantanız mevcut mu? }\end{array}$ & ,793 & & & \\
\hline $\begin{array}{l}\text { Afet durumunda kullanmak üzeri stokla- } \\
\text { dığınız su ve gıda ürünleriniz var mı? }\end{array}$ & ,790 & & & \\
\hline $\begin{array}{l}\text { Evinizde devrilebilecek eşyalara karşı ted- } \\
\text { bir aldınız mı? }\end{array}$ & ,698 & & & \\
\hline $\begin{array}{l}\text { Evinizde ilkyardım malzemeleri ve ilaçları } \\
\text { içeren bir çanta ya da dolap mevcut mu? }\end{array}$ & ,657 & & & \\
\hline $\begin{array}{l}\text { Önemli evraklarınıza ilişkin tedbir aldınız } \\
\text { mı? }\end{array}$ & ,649 & & & \\
\hline $\begin{array}{l}\text { Evinizi doğal afetlere karşı sigortalattınız } \\
\text { mı? }\end{array}$ & ,544 & & & \\
\hline $\begin{array}{l}\text { Yaşadığınız semtin sakinleri ile muhtemel } \\
\text { bir afet durumunda yapılabilecek işler hu- } \\
\text { susunda herhangi bir toplantıya/eğitime } \\
\text { katıldınız mı? }\end{array}$ & 407 & & & \\
\hline $\begin{array}{l}\text { Afet durumunda aile üyesinin birbirinden } \\
\text { kopma ihtimaline karşı ortak bir buluşma } \\
\text { yeri belirlediniz mi? }\end{array}$ & & 848 & & \\
\hline $\begin{array}{l}\text { Afet durumu için aile içinde herhangi bir } \\
\text { planlama yaptınız mı? }\end{array}$ & & ,786 & & \\
\hline $\begin{array}{l}\text { Yaşadığınız bölgede önemli bir doğal afet } \\
\text { yaşanması durumunda nerede toplanıla- } \\
\text { cağını ailenizde herkes biliyor mu? }\end{array}$ & & ,747 & & \\
\hline $\begin{array}{l}\text { Doğal afet durumunda yardım talep ede- } \\
\text { bileceğiniz acil durum numaralarını aile- } \\
\text { nizde herkes biliyor mu? }\end{array}$ & & & ,780 & \\
\hline $\begin{array}{l}15 \text { yaş ve üzeri tüm aile üyeleriniz eviniz- } \\
\text { deki elektrik, su ve doğalgaz servislerini } \\
\text { nasıl kapatacakların biliyor mu? }\end{array}$ & & & ,770 & \\
\hline $\begin{array}{l}\text { Aile üyeleriniz içinde ilk yardım bilgilerine } \\
\text { sahip herhangi bir kimse var mı? }\end{array}$ & & & 606 & \\
\hline $\begin{array}{l}\text { Yaşadığınız semtte doğal afetlere karşı her- } \\
\text { hangi bir uyarı sistemi olup olmadığını bi- } \\
\text { liyor musunuz? }\end{array}$ & & & & 809 \\
\hline $\begin{array}{l}\text { Doğal afet uyarı sinyallerinden hangileri- } \\
\text { nin ne anlama geldiğini ailenizde herkes } \\
\text { biliyor mu? }\end{array}$ & & & & ,768 \\
\hline $\begin{array}{l}\text { Açklanan Toplam Varyans } \\
\text {,40'ın altındaki yükler gösterilmemiştir. }\end{array}$ & 34,47 & 10,65 & 7,97 & 6,89 \\
\hline
\end{tabular}


Tablo 7: Alt Boyut Skorları

\begin{tabular}{llll}
\hline & $\mathbf{N}$ & $\mathbf{X}$ & SS \\
\hline Afet Fiziksel Koruma & 1134 & 13,76 & 4,52 \\
\hline Afet Planlama & 1134 & 5,69 & 2,22 \\
\hline Afet Yardım & 1134 & 8,52 & 1,98 \\
\hline Afet Uyarı Sistemleri & 1134 & 3,60 & 1,43 \\
\hline
\end{tabular}

Tablo 8: Faktörler Arası Korelasyonlar

\begin{tabular}{lllll}
\hline & AFK & AP & AY & AUS \\
\hline AFK & 1 &, $584^{* *}$ &, $306^{* *}$ &, $399^{* *}$ \\
\hline AP & 1 &, $223^{* *}$ &, $399^{* *}$ \\
\hline AY & & 1 &, $159^{* *}$ \\
\hline AUS & & 1 \\
\hline${ }^{* *}$. Anlamlı korelasyonlar 0.01 aralı̆̆ında (2-kuyruklu). &
\end{tabular}

Doğrulayıcı Faktör Analizi sonucunda da AFA'da ortaya konulan yapının doğrulandığı görülmüştür.

Sümer'e (2000) göre DFA kuramsal bir temelden destek alarak pek çok değişkenden oluşturulan faktörlerin gerçek verilerle ne derece uyum gösterdiğini değerlendirmeye yönelik bir analizdir. Bir başka anlatımla DFA, önceden belirlenmiş ya da kurgulanmış bir yapının toplanan verilerle ne derece doğrulandığını incelemeyi amaçlar (Seçer, 2013 ).

Doğrulayıcı faktör analizinde pek çok test bulunmaktadır. Bunlar içerisinde en sık kullanılanları Bunlar içinde en sık kullanılanları, $x^{2}$, RMR veya RMS, GFI, AGFI, CFI, NFI, RMSEA'dır. GFI, CFI, NFI, RFI, IFI ve AGFI testleridir. Burada Gilles E. (2009)'in önerdiği kısmi doğrulayıcı faktör analizi kullanılarak, daha derine bakılıp bakılmasına gerek olup olmadığına karar verilmeye çalışılmışır.

Tablo 9: DFA Uyum ve İyilik Ölçütleri İlk Model

\begin{tabular}{lllll}
\hline Uyum Ölçüsü & Değeri & Normal Değer & $\begin{array}{l}\text { Kabul Edilebilir } \\
\text { Değer }\end{array}$ & Ölçütler \\
\hline $\mathrm{x}^{2}$ & 633 & - & & - \\
\hline $\mathrm{x}^{2} / \mathrm{SD}$ & 7,53 & $<2$ & $<5$ & Kabul edilemez \\
\hline RMSEA & 0,07 & $>0,05$ & $>0,08$ & Sinır değer \\
\hline GFI & 0.92 & $>0,95$ & $>0,90$ & Sinır değer \\
\hline AGFI & 0.89 & $>0,95$ & $>0,90$ & Sinır değer \\
\hline CFI & 0.90 & $>0,95$ & $>0,90$ & Sinır değer \\
\hline SRMR & 0,07 & $<0,05$ & $<0,08$ & Sinır değer \\
\hline RMR & 0,06 & $<0,05$ & $<0,08$ & Yeterli değer \\
\hline
\end{tabular}


Ki-kare/serbestlik derecesi istatistiği ( $\mathrm{x}^{2} / \mathrm{s} . \mathrm{d}$.), 7,53 çlkmış, bu da ciddi bir problem olarak gözükmüştür. Fakat $x^{2}$ istatistiğine ait $p$ değeri örneklem büyüklüğünden çok fazla etkilenir, (Çapık, 2014) yani uygulamada $x^{2}$ değeri genelde anlamlı çıkar (Şimşek, 2007). Diğer uyum indeksleri örneklem büyüklüğünden daha az etkilenir (Waltz, Strcikland ve Lenz, 2010). RMSEA (Ortalama hata karakök yaklaşımı - Root-mean-square error approximation) 0,07 bulunmuş Browne ve Cudeck (1993) e göre normal uyum olarak kabul edilmiştir. Bir diğer kriter, Goodness of Fit Index (GFI) ve AGFI (Uyarlanmış Uyum iyiliği indeksi - Goodness-of-fit index) dir. Birbirine çok yakın bu iki uyum testinden de normal sonuçlara ulaşılmıştır. Tabi ki şu gözden kaçırılmamalıdır ki, modelin karmaşıklığı arttıkça bu uyum indekslerine uyum da o kadar zorlaşacaktır (Anderson ve Gerbing, 1984).

$\mathrm{x}^{2} / \mathrm{s}$.d. istatistiğindeki problem yüzünden LISREL programının düzeltme önerileri (modification indicies) tablosu incelenmiş ve bu tabloya göre hareket edilerek modelin daha tutarlı hale getirilmesine çalışılmıştır (Şimşek 2007). AFK1 ve AFK2 (222 $x^{2}$ değişimi) ile AFK 3 ve AFK 5 (122 $x^{2}$ değişimi) soruları arasındaki ilişki sebebiyle ki-kare istatistiğinin problem çıarttığ gözlemlenmiş 2 ve 5 numaralı sorular ölçekten çıkartılmıştır.

Tablo 10: DFA Uyum ve İyilik Ölçütleri İkinci Model

\begin{tabular}{|c|c|c|c|c|}
\hline Uyum Ölçüsü & Değer & Normal Değer & $\begin{array}{l}\text { Kabul Edilebilir } \\
\text { Değer }\end{array}$ & 2. Model \\
\hline$x^{2}$ & 290,56 & - & & - \\
\hline $\mathrm{x}^{2} / \mathrm{SD}$ & 4,91 & $<2$ & $<5$ & $2<x<5$ arasinda \\
\hline RMSEA & 0,05 & $>0,05$ & $>0,08$ & Yeterli Uyum \\
\hline GFI & 0.96 & $>0,95$ & $>0,90$ & Yeterli Uyum \\
\hline AGFI & 0.94 & $>0,95$ & $>0,90$ & Yeterli Uyum \\
\hline CFI & 0.94 & $>0,95$ & $>0,90$ & Yeterli Uyum \\
\hline SRMR & 0,05 & $<0,05$ & $<0,08$ & Yeterli Uyum \\
\hline RMR & 0,04 & $<0,05$ & $<0,08$ & Yeterli Uyum \\
\hline
\end{tabular}

Ki-kare istatistiği ( $x^{2} /$ s.d.) ikinci modelde, 4,91 çıkmış Beş ve daha az ise kabul edilebilir bir değerdir (Çapık, 2014; Hooper, Coughlan, Mullen 2008; Munro, 2005; Şimşek 2007). RMSEA (Ortalama hata karakök yaklaşımı Root-mean-square error approximation) 0,05 bulunmuş Browne ve Cudeck (1993) e göre normal uyum olarak kabul edilmiştir. Bir diğer kriter, Goodness of Fit Index (GFI) ve AGFI (Uyarlanmış Uyum iyiliği indeksi - Goodness-offit index) dir. Birbirine çok yakın bu iki uyum testinden de iyi sonuçlara ulaşılmıştır. Aynı şekilde CFI'nın yükseldiği gözlemlenmiştir $(0,094)$. 
Lisrel 9.2. programı ile incelenen tüm DFA ile tahminlenen faktör yüklerinin anlamlılığını veren $t$ değerleri tamamı anlamlı çıkmıştır. (Şekil 1.) Jöreskog ve Sörbom (1996) $t$ değerleri ile ilgili kırmızı ok bulunmamasının tüm maddelerin 0,05 düzeyinde anlamlı olduğunu ifade etmektedir. $t$ değerlerinde kırmızı ok bulunmaması tüm maddelerin 0,05 düzeyinde anlamlı olduğunu göstermiştir. AFK alt boyutu için ,74 ile ,45 arası, AP için ,75 ila ,85 arası, AY için ,57 ile ,79 arası AUS için de ,81 ila ,76 arası faktör yüklerine ulaşılmıştir.

Tablo 11: İkinci Model Faktör Yükleri

\begin{tabular}{|c|c|c|c|c|}
\hline & \multicolumn{4}{|c|}{ Faktörler } \\
\hline & $\begin{array}{l}\text { Afet } \\
\text { Fiziksel } \\
\text { Koruma } \\
\text { (AFK) }\end{array}$ & $\begin{array}{l}\text { Afet } \\
\text { Plan- } \\
\text { lama } \\
\text { (AP) }\end{array}$ & $\begin{array}{l}\text { Afet } \\
\text { Yar- } \\
\text { dım } \\
\text { (AY) }\end{array}$ & $\begin{array}{l}\text { Afet Uyarı } \\
\text { ve Sinyaller } \\
\text { (AUS) }\end{array}$ \\
\hline $\begin{array}{l}\text { Afet durumunda ihtiyaç duyacağınız malzemeleri } \\
\text { içeren afet çantanız mevcut mu? }\end{array}$ &, 74 & & & \\
\hline $\begin{array}{l}\text { Evinizde devrilebilecek eşyalara karşı tedbir aldınız } \\
\text { mı? }\end{array}$ & ,70 & & & \\
\hline $\begin{array}{l}\text { Evinizde ilkyardım malzemeleri ve ilaçları içeren bir } \\
\text { çanta ya da dolap mevcut mu? }\end{array}$ & 66 & & & \\
\hline Evinizi doğal afetlere karşı sigortalattınız mı? & 65 & & & \\
\hline $\begin{array}{l}\text { Yaşadığınız semtin sakinleri ile muhtemel bir afet } \\
\text { durumunda yapılabilecek işler hususunda herhangi } \\
\text { bir toplantıya/eğitime katıldınız mı? }\end{array}$ & ,45 & & & \\
\hline $\begin{array}{l}\text { Afet durumunda aile üyesinin birbirinden kopma } \\
\text { ihtimaline karşı ortak bir buluşma yeri belirlediniz } \\
\text { mi? }\end{array}$ & & ,85 & & \\
\hline $\begin{array}{l}\text { Afet durumu için aile içinde herhangi bir planlama } \\
\text { yaptınız mı? }\end{array}$ & & ,79 & & \\
\hline $\begin{array}{l}\text { Yaşadığınız bölgede önemli bir doğal afet yaşan- } \\
\text { ması durumunda nerede toplanılacağını ailenizde } \\
\text { herkes biliyor mu? }\end{array}$ & & 75 & & \\
\hline $\begin{array}{l}\text { Doğal afet durumunda yardım talep edebileceğiniz } \\
\text { acil durum numaralarını ailenizde herkes biliyor } \\
\text { mu? }\end{array}$ & & & ,79 & \\
\hline $\begin{array}{l}15 \text { yaş ve üzeri tüm aile üyeleriniz evinizdeki } \\
\text { elektrik, su ve doğalgaz servislerini nasıl } \\
\text { kapatacaklarını biliyor mu? }\end{array}$ & & & ,78 & \\
\hline $\begin{array}{l}\text { Aile üyeleriniz içinde ilk yardım bilgilerine sahip } \\
\text { herhangi bir kimse var mı? }\end{array}$ & & &, 57 & \\
\hline $\begin{array}{l}\text { Yaşadığınız semtte doğal afetlere karşı herhangi bir } \\
\text { uyarı sistemi olup olmadığını biliyor musunuz? }\end{array}$ & & & & 81 \\
\hline $\begin{array}{l}\text { Doğal afet uyarı sinyallerinden hangilerinin ne an- } \\
\text { lama geldiğini ailenizde herkes biliyor mu? }\end{array}$ & & & & ,76 \\
\hline $\begin{array}{l}\text { Açılanan Toplam Varyans } \\
\text {,40'ın altındaki yükler gösterilmemiştir. }\end{array}$ & 33,45 & 11,69 & 8,13 & 7,17 \\
\hline
\end{tabular}


İkinci model ile birlikte varyanslarda çok küçük değişiklikler olduğu gözlemlenmiş çıarılan sorular Afet Fiziksel Koruma alt boyutundan olduğu için, Sadece bu alt boyutun ortalama değeri 13,76'dan 9,97'ye, standart sapması 3,35'e düşmüştür.

Tablo 12: Alt Boyut Skorlar1

\begin{tabular}{llll}
\hline & N & X & SS \\
\hline Afet Fiziksel Koruma & 1134 & 9,97 & 3,35 \\
\hline Afet Planlama & 1134 & 5,69 & 2,22 \\
\hline Afet Yardım & 1134 & 8,52 & 1,98 \\
\hline Afet Uyarı Sistemleri & 1134 & 3,60 & 1,43 \\
\hline
\end{tabular}

Ölçeğin 13 maddesinin güvenilirliği için Cronbach Alfa iç tutarlılık katsayısı hesaplanmıştır. İç tutarlılık katsayısının 0,82 olduğu gözlemlenmiştir. Madde silinmesi halinde alpha değerinin yükseleceğine dair bir durum gözlemlenmemiştir. Elde edilen değerler, bu ölçeğin Afet ve Hazır Bulunuşluk Ölçeği (AHBÖ) güvenilir bir ölçme aracı olduğunu göstermektedir.

\section{Sonuç ve Öneriler}

Bu araştırmada Balıkesir evreninden TÜİK vasıtası ile oluşturulan örneklem ile Balıkesir ilinde binin üzerinde hane halkına ulaşılarak ( $N=1134)$ afet hazırbulunuşluk ölçeği oluşturulmaya çalışılmıştır. Elimizdeki anketi faktör yükleri üzerinden ölçeğe çevirmek için ilk olarak 26 soruluk havuzda toplanan tüm soruların SPSS ile faktör analizi yapılmış, ardından faktör analizi yöntemi ile elde edilen 15 soru ile faktör yükleri belirlenmiştir. Ölçek geliştirme sürecinin önemli bir parçası olan LISREL programına geçilerek 15 soruluk 4 faktörlü yapı, analize sokulmuştur. Analiz sonrasında uyum iyilik ölçütleri ile ilgili özellikle katı bir ölçüt olan ki-kare/serbestlik derecesi istatistiği değerinin olumsuz çıkması sonucunda kurulan modelden vazgeçilmiştir. LISREL programının ürettiği değiştirme indeksleri (modificaiton indicies) tabloları incelenerek yeni bir yapı oluşturulmuş ve analiz tekrarlanmıştır. İkinci model, 13 soruluk bir modele dönüşmüştür. İkinci modelin uyum iyilik ölçütlerinden normal puanlar aldığı ve evrensel kabul edilen değerlere uyduğu gösterilmiştir. Veri yolu analizi yapılarak şekil olarak rapor edilmiştir. SPSS programı tekrar kullanılarak sağlaması yapılmış ve ölçek geliştirme süreci tamamlanmıştır.

Bu araştırmanın en büyük sınırlılığı Balıkesir evren ve örneklemini kapsamasıdır. Her ne kadar ülkemiz bütünüyle afetlere açık bir ülke olsa da Balı- 
kesir bu kapsamdaki pek çok ilden biridir. Bu araştırmanın güçlü gözükebilecek yanı ise bir ilin evreninden tam örneklem çekilmiş olmasıdır. Bu anlamda araştırma, hem kent hem de kır bölgesini kapsamaktadır. Bu araştırmanın gerek diğer illerde gerekse ulusal boyutta tekrarlanması araştırmaciların en büyük dileğidir. Böylelikle ölçeğin dış geçerliliği daha da kuvvetlenecektir.

Bu ölçeğin alt boyutlarında belirtilen planlama, bilgi/beceri, genel olarak hazırbulunuşluk unsurları göz önüne alınarak çeşitli afetlerle sinanan ülkemizin afetlere karşı daha dirençli olmasına katkıda bulunması amaçlanmaktadır. Bu ölçek yardımıyla, bunun gibi çalışmaların mikro ve makro düzeylerde yaygınlaşması en büyük önceliktir. Alınacak sonuçlar tüm paydaşlara yapılması gerekenlerin planlanmasını kolaylaştıracaktır. Kullanılması ve yaygınlaşması, geliştirdiğimiz ölçeğin en önemli artısı olacaktır. Bunun bir adım sonrası olarak ölçeğin vereceği sonuçların dikkate alınması ve bu dikkate alınma ile birlikte afetlere yönelik çalışmaların ve planlamaların geliştirilmesi en büyük hedef ve öneri olacaktır. Çünkü afetlerde kaybedilen her can bu araştırmanın konusu olan sayıların ve istatistiğin ötesinde bir yaşam öyküsü, bir tekillik, bir sorumluluktur.

\section{Teşekkür}

Bu makale TÜBITAK tarafından desteklenen 116K208 numaralı "AİLE, YEREL TOPLULUK VE DOĞAL AFETLER: Farkındalık, Hazırlık, Güven ve Sosyal Sermaye Açılarından Sosyolojik Bir İnceleme" adlı projenin verilerinin bir kısmı kullanılarak hazırlanmıştır. Yazarlar TÜBİTAK'a desteği için teşekkür eder. 


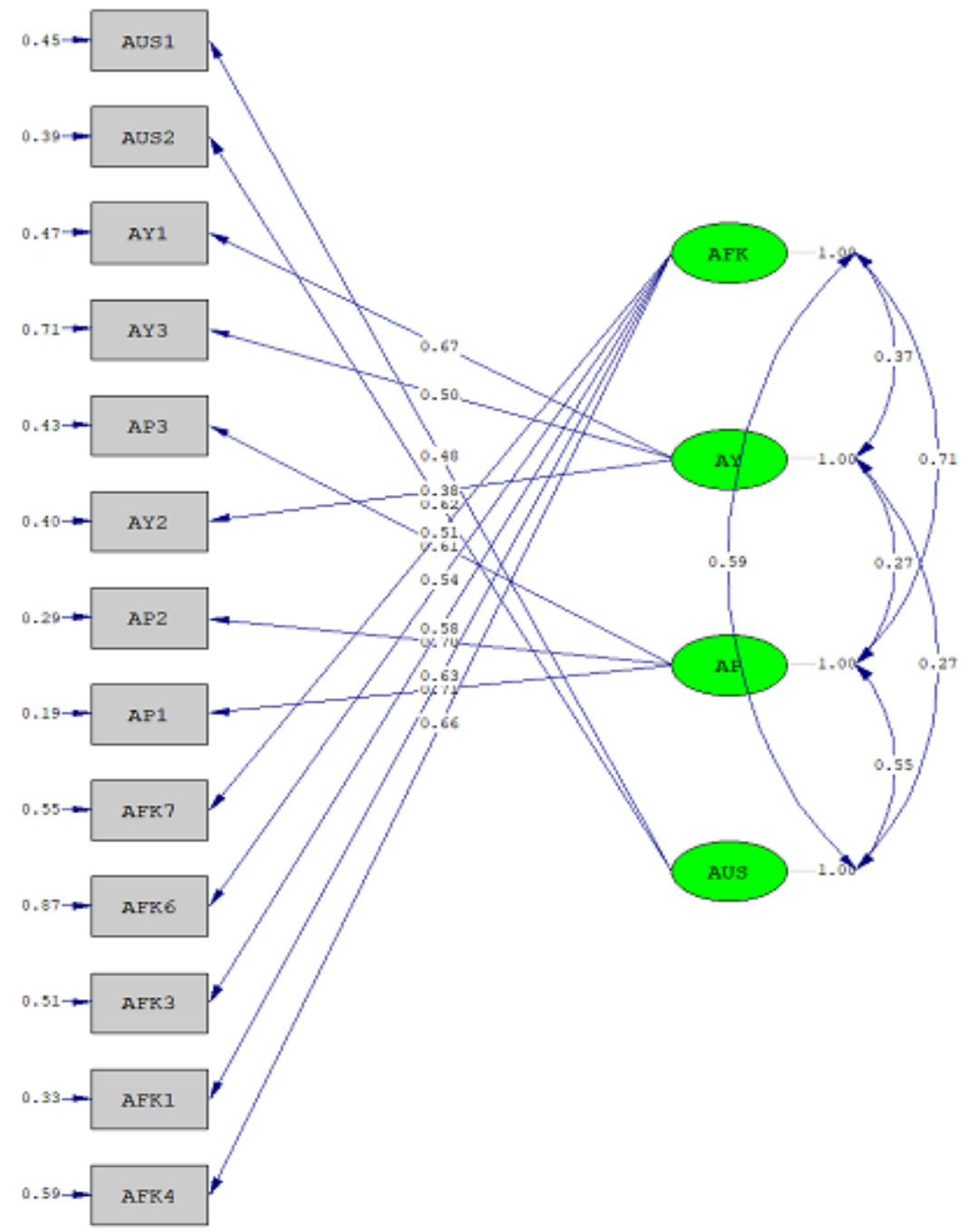

Chi-Sqasre-290.56, dt-59, P-walue-0.00000, RMSEA-0.059

Şekil 1: Veri Yolu Analizi (Path Diagram). 


\section{Extended Abstract}

\section{A Scale Development Study in Balıkesir Sampling: Disaster Preparedness Scale}

\author{
Barış Şentuna \\ ORCID: 0000-0001-9982-8382
}

\author{
Fahri Çakı \\ ORCID: 0000-0002-8895-2297
}

Disaster preparedness refers to reduction of risks and dangers caused by disasters by planning, applications, and assessments, starting from households up to national level. This article aims to develop a universal scale for measuring disaster preparedness of households using Balıkesir sample. This article is consists of four main parts. In first part of this article, concept of preparedness is examined and definition of preparedness is provided. In addition to this, the scales developed for measuring preparedness are analyzed, compared and presented.

In second part, the preparing of sampling from universe Balıkesir is explained in numbers $(\mathrm{N}=1134)$. Total population of Balıkesir province is 1.196.176. This research focuses on households rather than individuals. There are 395,499 households in Balıkesir. Using the formulas the sampling is calculated as 1065 households. There are 20 districts and 892 villages in Balıkesir. Based on Turkish Statistics Institute data, the sampling is divided to \%60 city and $\% 40$ rural areas. Throughout the research 12 districts, 75 neighborhoods and 43 villages are visited by the researchers. A pool of 26 questions are identified by researchers, but this pool was reduced to 15 questions based on the fact that $\% 40$ of the question will be made in rural areas therefore the questions has to be kept in their simplest form. 1500 questionnaires were aimed, 1134 were gathered from the households. $(\mathrm{N}=1134)$

In third part, the findings are presented. Explanatory factor analysis was made using Varimax method in SPSS. Cronbach Alpha values were found high confidence as well as the other pre-tests Kaiser-Meyer-Oklin and Barlett's sphericity test were found at good levels to run factor analysis. Factor analysis in SPSS revealed 4 factors and 15 questions. After explanatory factor analysis, as 
the important part of scale development phase, confirmatory factor analysis is made by LISREL. Confirmatory factor analysis revealed the goodness of fit indexes. Based on the results it is seen that one of the most strict rules of scale development namely $x^{2}$ / SD (chi-square/ degrees of freedom) was found 7,53 which is far above the accepted values $2<x<5$. This situation also proves that explanatory factor analysis is not alone enough for scale development. For the problems that can cause these values modification indices table was screened. It is observed that the problem resulted from the inter-relation of the questions in Disaster Physical Protection (DFP) so that the lowest scored question was removed from the scale. Those were questions 2 and 5 of 15 questions scale. After removing the question the new value of $x^{2}$ /SD was found as 4,91 which is in acceptable range. It was observed that other goodness of fit indexes were also scored higher like RMSEA $(0,05)$, GFI $(0,96)$, AGFI $(0,94)$, CFI $(0,94)$, SRMR $(0,05), \operatorname{RMR}(0,04)$. All the $t$ values as expected values were found significant.

As a result Disaster Preparedness Scale is made up of 15 questions and 4 dimensions. Scale explains 59,99 of all variances. 4 factors respectively are named as: Disaster Physical Protection (DFP), Disaster Planning (DP), Disaster Help (DH), Disaster Warning and Signals (DWS). Disaster Physical Protection (DFP) is made up of 5 items factor loadings between ,74 and ,45; with a mean score of $13,76(X=13,76 ; S S=4,52, N=1134$; see Table 6.) and explains 34,47 of total variance. Disaster Planning (DP) is made of 3 items with factor loadings between ,84 and ,75; with a mean of 5,69 ( $X=5,92 ; S S=2,22, N=1134)$ and explains 10,65 of total variance. Disaster Help (DH) is made up of 3 items factor loadings change between ,78 and ,60; with a mean of $8,52(X=8,52 ; S S=1,98, N=1134)$ and explains 7,97 of total variance. Disaster Warning and Signals (DWS) is made up of 2 items factor loadings range from , 80 and ,76; with a mean of $3,60(X=3,60$; $\mathrm{SS}=1,43, \mathrm{~N}=1134$ ); and explains 6,89 of total variance. The 13 questions of this scale inner reliability is calculated by SPSS the Cronbach Alpha value is found as 0,82 . There were no cases if item deleted the score will rise. One of the most important part of developing scale namely path diagram made by LISREL is given.

In fourth part results are presented and suggestions are provided. The most important limitation of this study is that it covers Balıkesir universe and sampling. Although Turkey is open to various disasters and Balıkesir is one of those provinces prone to lots of disasters, for that limitation this scale has to be used in different provinces, if possible different countries. The strong side of this research is that a full sampling is made from a total provenance. From that 
perspective, this research includes both rural and urban areas. The most important desire of the researchers is repeating of this scale in other provinces if possible different countries. Therefore, the outer reliability of the scale will be stronger.

In the dimensions of this scale stated as disaster planning, disaster help in general preparedness factors will help to provide more resilience against disasters as a country, tested by various disasters over and over again. By the help of this scale and scales like this one, it is the most important priority researches like this one will be made more frequently. If the results by those researches are shared with all the actors, this will make the planning easier and cleverly. As one step further, the most important suggestion of this scale is that the usage of this scale in all areas and with information provided by the society be recognized and paid attention in order to plan for future disasters preparedness rise. Because each soul and live that is lost in a disaster, is far beyond the subject of this research, the numbers, the statistics. Every lost life is life story, a singularity, and a responsibility.

\section{Kaynakça/References}

Anderson, J. C. ve Gerbing, D. W. (1984). The effect of Sampling Error on Convergence, Improper Solutions, and Goodness-of-fit Indices for Maximum Likelihood Confirmatory Factor Analysis. Psychometrika, 49, 155-173.

Baker, E.J. (2011). Household preparedness for the Aftermath of Hurricanes in Florida. Applied Geography, 31(1), 46-52.

Bartlett, M. S. (1954). A note on the multiplying factors for various approximations. J. Roy. Statisi. Soc. B., 16, 296-298.

Browne, M. W. ve Cudeck, R. (1993). Alternative ways of assessing model fit. Bollen K.A., Long J.S.,(Der.). Testing structural equation models. içinde(s. 111-135). Beverly Hills, CA: Sage.

Büyüköztürk, Ş. (2006). Sosyal Bilimler İçin Veri Analizi: İstatistik, Araştırma Deseni SPSS Uygulamaları ve Yorum. Ankara: PegemA Yayınclik.

Cardona, O. D. (2005, Ağustos). Indicators of Disaster Risk and Risk Management-Main Technical Report. IDB/IDEA Program of Indicators for Disaster Risk Management, National University of Colombia, Manizales. 4.11.2020 tarihinde http://idea.bid.manizales.unal.edu.co/documentos/Main\%20technical\%20report\%2 OIDEA.pdf adresinden erişildi.

Cartell R. B. (1966). The Shree test for number of factors. Multivariate Behavioral Research, $1,254-276$.

Çam, O.M. ve Baysan-Arabac L. (2010). Tutum Ölçeği Hazırlamada Nitel ve Nicel Adımlar. Hemşirelikte Araştırma Geliştirme Dergisi, 2, 59-71. 
Çapık, C. (2014). Geçerlik Ve Güvenirlik Çalışmalarında Doğrulayıc Faktör Analizinin Kullanım. Anadolu Hemşirelik ve Sağlık Bilimleri Dergisi, 17(3), 196-205.

Davidson, R.A. ve Lambert, K.B. (2001). Comparing the hurricane disaster risk of U.S. coastal counties. Natural Hazards Review, 2(3), 132-142.

Dikmenli, Y., Yakar, H., Konca, A. (2018). Development of Disaster Awareness Scale: A Validity and Reliability Study. Review of International Geographical Education Online (RIGEO), 8(2), 206-220. 17.12.2019 tarihinde http://www.rigeo.org/vol8no2/Number2Summer/RIGEO-V8-N2-2.pdf adresinden erişildi

Garland R. (1991). The Mid-Point on a Rating Scale: Is it Desirable?. Marketing Bulletin, 2, 66-70.

Gignac, G. E. (2009). Partial Confirmatory Factor Analysis: Described and Illustrated on the NEO-PIR. Journal of Personality Assessment, 91(1), 40-47.

Hazırbulunuşluk. (2020, 20 Aralık). Cambridge English Dictionary içinde. Erişim adresi: https://dictionary.cambridge.org/us/dictionary/english/preparedness

Hooper D., Coughlan J., Mullen M.R. (2008) Structural Equation Modelling: Guidelines for Determining

Model Fit. Electronic Journal of Business Research Methods, 6(1), 53-60.

Ilo, P. I., Izuagbe, R., Mole, A. J. C., Ekwueme, L. (2018). Measuring disaster preparedness and response practices in university libraries in Nigeria: The role of disaster equipment. International Journal of Disaster Risk Reduction, 31, 85-91.

Jöreskog, K. G. ve Sörbom, D. (1989). LISREL 7 User's Reference Guide. Chicago: SPSS Publications.

Kaiser, H. F. (1970). A second generation little jiffy. Psychometrika, 35, 401-416.

Munro, B.H. (2005) Statistical Methods For Health Care Research. Philadelphia: Lippincott Williams \&Wilkins, 351-376.

Nishigami, A. (2015). Development of Natural Disaster Preparedness Scale for Nursing Department of Hospital: Reliability and Validity as Scale. Journal of Japan Academy of Nursing Science, 35, 257-266.

Patrisina, R., Faradissa Emetia, F., Sirivongpaisal, N.,Suthummanon, S., Alfadhlani, A., veFatrias, D. (2018, Ekim). Key performance indicators of disaster preparedness: a case study of a tsunami disaster. ICDM 2018 konferansinda sunulan bildiri, Singapur. https://doi.org/10.1051/matecconf/201822901010 adresinden erişilmiştir.

Rachmalia, M.N.S., Urai Hatthakit R.N., Aranya Chaowalit, A.P.N. (2011). Tsunami preparedness of people living in affected and non-affected areas: A comparative study in coastal area in Aceh, Indonesia. Australasian Emergency Nursing Journal, 14(1), 17-25.

Rañesesa, K., Chang-Richardsa, A., Richardsb, J., Bubb, J. (2018, Kasim). Using scientific knowledge to inform policy and practice in disaster risk reduction. Measuring the level of disaster preparedness in Auckland. 7th International Conference on Building Resilience konferansinda bunulan Bildiri, Bangkok, Tayland. https://isiarticles.com/bundles/Article/pre/pdf/137304.pdf adresinden erişilmiştir. 
Seçer İ. (2013) SPSS ve LISREL ile Pratik Veri Analizi Analiz ve Raporlaştırma. Anı Yayıncllık, Ankara.

Sümer, N. (2000). Yapısal Eşitlik modelleri: Temel kavramlar ve Örnek Uygulama. Türk Psikoloji Yazıları, 3(6), 49-73.

Simpson, D. (2008). Disaster preparedness measures: a test case development and application. Disaster Prevention and Management, 17(5), 645-661.

Şencan H. (2005). Sosyal ve Davranışsal Ölçümlerde Güvenilirlik ve Geçerlilik. Ankara.

Şimşek, Ö.F. (2007). Yapısal eşitlik modellemesine giriş, temel ilkeler ve LISREL Uygulamaları. Ankara: Ekinoks. p.4-22.

Tabachnick, B. G. ve Fidell, L. S. (2001). Using Multivariate Statistics (4. Bs.). Needham Heights: Allyn \& Bacon.

Vahle, T., Beatty, G. (1993). Emergency Management Guide for Business \& Industry. Federal Management Agency. $6.11 .2020 \quad$ tarihinde http://www.Fema.Gov/Pdf/Business/Guide/Bizindst.Pdf adersinden erişildi.

Waltz C.F., Strcikland O.L., Lenz E.R. (2010). Measurement in Nursing and Health Research. New York: SpringerPublishing Company.

Walker, J.T. ve Maddan, S. (2013). Underslanding statistics for the social Sciences, criminal justice, and criminology. Wall Street: Jones and Bartlett Learning.

World Health Organization. (2011, Haziran) Comparative analysis of national pandemic influenza preparedness plans. Erişim adresi: https://www.who.int/influenza/resources/documents/comparative_analysis_php_ 2011_en.pdfExternLink

World Health Organization, Emergency and Humanitarian Action (WHO/EHA). (2002). Disasters E emergencies: Definitions (Training Package). Addis Ababa, Ethiopia: Panafrican Emergency Training Centre, WHO/EHA. http://apps.who. int/disasters/repo/7656.pdf adresinden erişilmiştir. 


\section{Ekler}

Ek-1: Sosyal Sermaye Ölçeğinin İngilizcesi

\begin{tabular}{|c|c|c|c|c|}
\hline \multicolumn{5}{|l|}{ Disaster Preparedness Scale } \\
\hline & 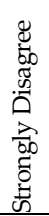 & 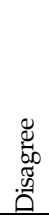 & $\underset{\mathscr{Z}}{\mathbb{Z}}$ & 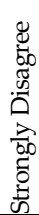 \\
\hline \multicolumn{5}{|l|}{$\begin{array}{l}\text { Do you have a disaster bag that can be used in time of } \\
\text { disaster including the materials you need? }\end{array}$} \\
\hline \multicolumn{5}{|l|}{$\begin{array}{l}\text { Did you take any precautions for the furniture that can } \\
\text { tilt over? }\end{array}$} \\
\hline \multicolumn{5}{|l|}{$\begin{array}{l}\text { In your house, do you have bag or cabinet including first } \\
\text { aid materials? }\end{array}$} \\
\hline \multicolumn{5}{|l|}{$\begin{array}{l}\text { Did you make insurance for your house against natural } \\
\text { disasters? }\end{array}$} \\
\hline \multicolumn{5}{|l|}{$\begin{array}{l}\text { Did you attend any meeting/education together with } \\
\text { your neighbors concerning what can be done at the time } \\
\text { of disasters? }\end{array}$} \\
\hline \multicolumn{5}{|l|}{$\begin{array}{l}\text { Together with you family, did you plan a place for } \\
\text { gathering for any possible separation? }\end{array}$} \\
\hline \multicolumn{5}{|l|}{$\begin{array}{l}\text { Did you do any planning inside your family for any } \\
\text { disaster? }\end{array}$} \\
\hline \multicolumn{5}{|l|}{$\begin{array}{l}\text { Does everybody in you neighborhood know the } \\
\text { meeting point in the time of disaster? }\end{array}$} \\
\hline \multicolumn{5}{|l|}{$\begin{array}{l}\text { In the time of natural disaster, does everyone in your } \\
\text { family know emergency telephone numbers needed for } \\
\text { help? }\end{array}$} \\
\hline \multicolumn{5}{|l|}{$\begin{array}{l}\text { Does everyone in your home over } 15 \text { years of age know } \\
\text { how to turn off electric, water and natural gas? }\end{array}$} \\
\hline \multicolumn{5}{|l|}{ In your family, is there anyone who knows first aid? } \\
\hline \multicolumn{5}{|l|}{$\begin{array}{l}\text { In your neighborhood do you know any signals or } \\
\text { warning systems for natural disasters? }\end{array}$} \\
\hline $\begin{array}{l}\text { Does everyone in your family know what warning } \\
\text { signals mean in your family? }\end{array}$ & & & & \\
\hline
\end{tabular}

